\title{
Nabokov's Freedom: An Uneven Battle against the Sinister Narrator
}

Fazel Asadi Amjad ${ }^{1}$, Bahare Jalali Farahani ${ }^{1}$, Javad Momeni*

${ }^{1}$ Department of Foreign Languages and Literatures, Kharazmi University, Tehran, Iran,

${ }^{2}$ Department of Foreign Languages and Literatures, University of Tehran, Tehran, Iran

Corresponding Author: Javad Momeni, E-mail: j.momeni364@yahoo.com

\section{ARTICLE INFO}

\section{Article history}

Received: May 21, 2017

Accepted: July 27, 2017

Published: December 01, 2017

Volume: 6 Issue: 7

Special Issue on Language \& Literature

Advance access: September 2017

Conflicts of interest: None

Funding: None

\begin{abstract}
With the recent inclination toward reading for ideological aspects of his works, Nabokov, who had been pervasively regarded as a mere ingenious aesthete, both during his life and for a long time after his death, has proved more puzzling in interpretation than what scholars believed. In this research, in order to understand what concept of freedom Nabokov has developed in his Bend Sinister, we focus on the two of his salient concerns: reality and individuality. Consequently, our narratological reading of Bend Sinister is concentrated first on the interpretation of the whatness of reality and its contribution to realize freedom, and second on analyzing the significance of retaining individuality to procure freedom; ultimately, out of delving into these two issues, the concept of freedom that the narrative techniques of the novel render, in correspondence to the peculiarities of the mid-twentieth century, is found out. Regarding the notion of the reality, in this novel, the unremitting propaganda of the totalitarian system presented the materialistic world as the ultimate truth, confining citizens in the prison of a fake world and not permitting them to gain the slightest awareness of the endless freedom possible in eternity. As to the individuality, Krug's attempts not to succumb to the desired system of padograph lead him to maintain his individuality and partly realize his freedom of mind. And finally, it is shown how totalitarianism has reached such absolute power that no thorough freedom of mind is now conceivable for humanity.
\end{abstract}

Key words: Freedom of Mind, Totalitarianism, Reality, Individuality, Intrusive Author-narrator

\section{INTRODUCTION}

In Bend Sinister, Nabokov's deliberate violation of the border between real and fantastic makes it difficult for readers and critics to come into a conclusion whether to consider this narrative a serious critique of modern despotism or a mere play with literary conventions. This question was reinforced by the author's introduction in which he stated his disdain for those of his audience who look for political clues in the novel (Nabokov 5), yet as it is usual for a Nabokovian peritext, considering this claim reliable is itself the matter of much dispute. However, the blatant political inclination of Bend Sinister is hard to be found in any other work by Nabokov. This opposition is due to the contradiction between aesthetics and ethics in his works; nevertheless, as Foster asserts the influence of dictatorial regimes in Nazi Germany and Communist Russia, alongside the destructive power of philistine culture is discernible in this narrative (28). In our search for the ideological presentation of genuine freedom in Bend Sinister we rely on Nabokov's own thesis, "I never meant to deny the moral impact of art which is certainly inherent in every genuine work of art"; what he avoided vehemently was "deliberate moralizing" (Nabokov and Bruccoli 59).

To find out what concept of freedom this extremist individualist developed in the turbulence of the era that had undergone two World Wars, we focus on two of his salient concerns. To Nabokov what each individual perceives of reality and what they embroider in their imagination are greatly venerated as much as the sense of individuality and independence from the standards of the masses are vital to him. Consequently, our narratological reading of Bend Sinister is dedicated to first the interpretation of the whatness of reality and its contribution to achieve freedom, and second to scrutinizing the significance of retaining individuality to procure freedom; ultimately, out of the answers to these two questions, the concept of freedom that the narrative techniques of the novel render, in correspondence to the peculiarities of the mid-twentieth century, is found out. The efforts to illustrate the interwoven relationship between reality, individuality and freedom through focusing on 'freedom of mind' become of primary importance as we note that no one has studied this interrelationship in Nabokov's novel up to now.

As to the narratological approach of our study, the method we have adopted is orientated towards the recent wave of Narrative theory which is mainly informed by postclassical narratologists who emphasize the fact that this is reading which shapes the text. The inception of ideological analysis has been traced first by Booth's concept of "implied author" which is centered on the assessment of both the audience's 
responses and the implied ideologies of the texts. In this manner, as Momeni and Jalali Farahani argue, Narrative theory entails an ideological approach by conceding that there is a design behind texts that affects readers in a particular way and that can be found through the words, techniques, and the intertextuality of the work by getting help in this process from readers' responses. Such rhetorically-oriented approach permits readers' ideological mindsets to form their readings and allows for the openness of reader-response criticism as the new wave of Narrative theory (1151-52).

The very first step we take in our narratological discussion of the text is to analyze its fabula. The vitality of distinguishing fabula from sjuzhet lies in the early narratologists' perspective that interpretation of a work is dependent on its underlying semiotic system than on its discourse. Yet, the distinction between these two terms has been considered as somewhat arbitrary by modern narrative theorists who argue that what is rendered is so strongly interrelated with how it is rendered that they cannot be separated from each other or we lose something important in this split. As Rimmon- Kenan has truly observed all narratives are style, language and medium-dependent (9). Thus, the fabula of this novel is decoded to perceive the main thesis of the work, and then its sjuzhet is scrutinized in order to find the ultimate picture of the author's design. Based on Kafalenos' five stages of fabula, Bend Sinister is a narrative about Adam Krug, a prominent professor of philosophy enjoying the perfect sense of 'equilibrium', who undergoes the state of 'disruption' as he finds himself entrapped by the totalitarian system that imposes pure conformity on him. The goal this hero looks for, then, is his and his son's freedom, and he tries to 'alleviate the disruption' by resisting the dictator, then escaping from him, and at the end by accepting to be at his service in exchange for his son's emancipation. Yet, his attempt to save David is unfruitful and in the fourth stage he 'fails'. By losing his sanity and then forcefully being saved by the author, Krug enters the fifth stage of a 'new equilibrium', though this phase of balance and peace is not a satisfactory one.

Based on the pattern of three myths, those of return, arrive, and surprise of the ending discerned by Boyd in Nabokov's works (36), the fabula of Bend Sinister can be also deciphered in terms of Krug's vain attempt to 'return' to the life he had before his wife's death and before being hunted by the police state of the totalitarian regime, leading to his pointless belief in the myth of 'arrival' or the possibility of controlling his future, and at the end an unconceivable ending of Krug's life (the myth of 'surprising end') in which he understands his fictionality and is saved, out of pity, by his sentimentalist author-god. The challenging question raised by the sjuzhet is whether to take Krug's being saved by his creator as a real salvation or as a disturbing, dictatorial intrusion that forces fake redemption on the protagonist, initially by stealing his sanity away, and then by blocking his access to the hereafter of eternity and absolute freedom. Bearing in mind Nabokov's mystical notions, his faith in a timeless and transcendental world and his intuition of the hereafter (Alexandrov 566-67), the dark ending of the narrative becomes more tangible. This curious rescue of the protagonist has been already addressed by critics like Walter who proposed that there is no victorious overcoming of the dictator by the protagonist in this narrative, and if there is any message of hope in this novel, it should be looked for in the absurdity, or even unreality of Ekwilism (36).

\section{TO BE OR NOT TO BE: IS IT REAL? THAT IS THE QUESTION}

It is evident that some of the vital "messages" (Nabokov 11) of the work are encoded within, and transferred through dreams that Krug sees from time to time. As an instance, the author himself explained the message behind one of Krug's dreams of his late wife- that as Krug watches her divesting her jewelry, she is symbolically releasing herself from earthly life- to signal the vitality of understanding the protagonist's dreams. In a panoramic view of the narrative, nevertheless, it seems that the whole text, all the scenes and actions are but mere parts of a dream seen by the author while they represent, simultaneously, parts of a character, Krug's dreams. This has been considered by critics like Grishakova as the author-narrator's dream of Krug's life (266).

This utilization of domineering dreams shatters all the realistic descriptions of people, state, and political atmosphere in the narrative, and therefore, it becomes specifically influential to comprehend the reason stimulating such context. The narrative arrangement of the text makes the border between dream and reality strikingly imperceptible. The description of Krug's dreams is interwoven too tightly within the stream of the narrative that only the author-narrator's apprising can help readers to discriminate between the protagonist's dreams and the main stream of the text. As an instance, chapter 16 contains the contemplations of Krug's on the bridge that had been already introduced to the audience as a usual pathway to Krug's house, and some crucial events of the novel had taken place on it, yet that very scene and the contemplations come out, suddenly, to be a dream. This is what scholars regard as the "intermediary" state of Adam who struggles to find a firm position for himself between reality and dream, as between autonomy and solidarity, and life and death (Grishakova 257). What should be specifically noted is the atmosphere such use of nightmares and fantasies create; what readers struggle to figure out, above all, is the fragile border between reality and dream.

In number of cases, distinguishing between what happens to Krug and what he dreams of becomes even harder as one should first determine whether the pronouns utilized are referring to the protagonist or to the author-narrator. The ' $I$ ' in chapter one can be Krug or the author-narrator. It also differs from the 'I' in the following chapters that usually refer to the narrator. As another instance, it is written in the initial part of chapter 8, after the arrest of Ember, Adam's intimate friend, "I must awake. The victims of my nightmares are increasing in number too fast, thought Krug" (112). This is another occasions that one cannot be sure this 'I' belongs to the protagonist or to the author-narrator. Begnal takes this shift in pronouns as testifying to the fact that Krug is dreaming one and the same time in a dream that he is only part of (25). In such a view, "the conscious layer of the dream interesting- 
ly resembles reality" that results in accumulation of diverse realities without the presence of an explicit border between dream and reality (Grishakova 98-99). Thus, it is the whatness of reality that is blatantly questioned in this work. On one side of the continuum, a true-to-life description of the setting and what takes place in the police state (although ludicrous in the nature of Ekwilist doctrines and in its unreasonable rules), the characters peopling the setting, and their conversations and viewpoints is provided for readers. On the other side of the continuum what the protagonist perceives and experiences seem utterly dreamlike. For Begnal, who considers this novel as an indictment of dictatorship, and yet more the manifestation of Adam Krug's love for his son and wife, what lurks behind this combination of dream and reality is an artistic dream that allows for transcending pain and coming to terms with the past (25). Even though such interpretation is very much close to what has been put forth by Nabokov in his introduction, it fails at touching the still more vital, political message lingering in the work.

As already discussed, Bend Sinister is taken to be the author-narrator's dream of Krug's life and this coupled with Grishakova's view that Nabokov borrowed the notion of the evil artist-creator from early Symbolists (94) hints to a political conclusion. We believe the omnipotent presence of the author-narrator who imposes his dream world and all the disasters to Krug can be regarded as the symbolic presentation of the constructed, fake world that system wishes to impose on his subjects, and to force them to live its lies. This philosopher is imprisoned in different layers of the nightmare that prevent him from realizing the truth of this fake world of the totalitarian regime.

In this play of dreams and nightmares where one cannot distinguish between events truly happening and fantasies Krug goes through, however, all that deals with the political system of this curious country feigns real life. Bend Sinister provides its readers with some basic information like the language people speak in (a mixture of Slavic and German), the name and background history of the dictator's life (that Paduk was a classmate of the protagonist and his father was a worthless inventor), the nature of the party he is the creator of and so forth. The nature of Ekwilist totalitarianism, from how it was initiated and who were the early members of the party, to what its motto and aims were are explained in detail. The immediate impression of such realistic illustration is the conspicuous affinity that readers detect between the narrative's tyranny and the despotic practices of Communist regime or Nazi Germany. Yet, what lurks behind such imitation of reality in case of the political government and its citizens is something beyond a reminder of real despotism in our modern times. What is implicitly rendered through this naturalistic picture is totalitarianism's intention to construct a fake reality for people in order to make them see the world- rules, justice, and government- through the medium that distorts, perfectly, what is indeed reasonable and acceptable. The idiotic rules are to be respected and practiced by people whom the author-narrator pities as "victims of Capitalism and Communism" (Nabokov 56) -in order to imply dictatorships' attempt at forcing people live unbelievably absurd lives. This juxtaposing the real with the fantastic, evident in chapter 17, where an apparent toy dog was accidentally hit by Krug but came to life and gave a snarl of pain, manifests Nabokov's manipulation of what is accepted as real (Rutledge 183). Also, it is a symbolic verification of the capability of a totalitarian system in making what is indeed real to be perceived as a mere artificial copy and vice versa.

In yet another, more explicit example of the system's constructing a fake version of the genuine, scrutinizing the reproduction of Shakespeare's Hamlet is much illuminating. The weird plot of this Ekwilist Hamlet is based on a professor Hamm's theory that the play is actually about how Fortinbras, "a blooming, young knight, beautiful and sound to the throne" (Nabokov 94) wishes to avenge his father's slain by Hamlet's father. In this rendering of the play, the protagonist is not Hamlet, but Fortinbras; the ghost in the first act is not Hamlet's but Fortinbras's, the father, and the invader is actually the savior of Danish people who were under the misrule of king Hamlet. The staging of "muddled Elizabethan" Hamlet according to Ember, who is responsible for directing this distorted version is an attempt by the government to demonstrate "the idea of mass justice", and that "if the nation desires to be worthy of a new, robust government, then everything must be changed" (Nabokov 95); a possible reference to the recent upheaval and the new government. Lee has observed the satiric element of this idiotic production that manifests racism and intense opposition of Individualism in the political dream of Ekwilism (200). This distorted version of Hamlet, bizarre and senseless testifies to the blatant attempt of the party at manipulating the original and turning it into a desired form. Such absurd rendering of the most prominent play in the world manifests, symbolically, totalitarianism's fake worldview that is spread and installed in citizens' minds as true and acceptable, forcing them unconsciously to yield to the hegemony of the system.

The sovereignty of such a dictatorial system is guaranteed by the help of propaganda, hinted at in the very beginning of the narrative, when one of those who had already succumbed to the new regime idealized the life under Ekwilism by dictating what should be taken as a perfect life. He then revealed the government's intention to educate (our emphasis) people to perceive only necessary (our emphasis) things in order to enjoy the perfect life of Average Man (Ekwilist) (Nabokov 25-26). Feigning a peerless world is achieved through dogmatic advocacy of those who are absorbed in the system, initially by trying to convince, and if not fruitful, compelling people to yield to the hegemony through education which is to be translated as distorting logic and truth. This realistic depiction of the regime and its mouthpieces reminds the propaganda of dictatorships like Nazi Germany that utilized absolute faith and reliance of the masses as the best propaganda, what the author and a great many of his audience had firsthand experience of. It is Nabokov's play, through language, with the concepts of real and fantastic that questions what readers deem as real and natural.

In new wave narrative theory, as Grishakova puts forth, all narratives are considered as the products of complex cultural transaction. It is clear that sociocultural construction 
of time and space is in close relation to the perception and experiences of each individual (14). Thus, due to the fact that Nabokovian works focus on the thoughts, feelings and worldviews of one single individual, the protagonist's views and perceptions of spatiotemporality, as the main concern of the novel are of prime importance. The limitation that time and space impose on human beings has been the matter of concern for Nabokov. Kuzmanovich argues that for many of Nabokov's characters there is a hope to trespass the boundaries of time and space, sometimes to reach to a more pleasant past in the presence of their loved ones, and sometimes to a "vantage point" whereupon they can have a glimpse of the world beyond their lives (24). Such desire is detectable in the contemplations of this lonely philosopher; his escape is both to his past, in the presence of his beloved Olga, right before the rise of Ekwilism, and to the realm of infinity and boundlessness.

Tangible is the sense of confinement that the passage of time engenders in Krug, and makes him yearn to trespass this limitation. However, his tight attachment to his past makes him impotent to take action in present, to decide about taking refuge in other countries- he is entrapped in the prison of time. This confinement is not induced only by the domineering past; the innate limitation of time as opposed to the inherent freedom of eternity is also disrupting to Krug. His struggle with the notion of eternity, an escape from time and space is evident throughout the narrative. As a philosopher, his "intelligence does not accept the transformation of physical discontinuity into permanent continuity" while it simultaneously rejects "the inanity of accumulating incalculable treasures of thought and sensation to be lost forever in infinite nothingness" (Nabokov 87). As argued by Ciancio, between the little that our finite consciousness perceives, and the great that humans have sense of lies the confining time and space. Thus, Krug, like many of other Nabokov's characters wishes to reach infinity, but as he has a glimpse of it, he is impotent to reach it (513-14). It is his incessant doubts, and the internal struggle with his own intuitions that drag him back to his finite life.

Space engenders a similar impression on the protagonist. In the multidimensional world of Bend Sinister the narratological discussion of space should be specifically centered on dreams. As already discussed in previous sections, there is no tangible border between dream and real world in this work. This can be regarded as an absence from three dimensional world of ours (Grishakova 232, 266). There is also a political dimension in the discussion of space in this work. In 1944, Nabokov put forth his own definition of poshlust (his peculiar spelling of poshlost meaning triviality and lack of spirituality) as a German offspring that is not limited to Germany only. Foster argues that Bend Sinister's depiction of tyranny makes readers reconsider "accustomed boundaries" (29); totalitarianism and philistinism can rise everywhere. Quite like other aspects of this novel, the sense of confinement that time and space convey is not limited to political inclinations of this narrative, rather, it manifests one underlying concern of the author, evident in many of his works; the question of immortality and hereafter.
Chapter fourteen of Bend Sinister is dedicated to the philosophical inquiries and contemplations of Krug who ponders about the whatness of outer and inner worlds, time, space and death, "death is either the instantaneous gaining of perfect knowledge...or absolute nothingness" (Nabokov 149). Of course he is unable to find clear cut answers, and finds himself impotent to write anything in response to these fundamental questions. This manifests Krug's constant occupation with transcendental matters, particularly with eternity or life after death. Schuman argues that Nabokov's creation in general presents the synthesis of aesthetic and ethical concerns in works with spiritual themes (52). In this very narrative, there is a philosopher who contemplates upon the possibility of life after death, and even cherishes it as an opportunity. Thinking of Etermon (the everyman that the system introduces as the ideal citizen in a cartoon series that got published in a bourgeois newspaper) who is rendered as if there is no death disturbing his and his wife's banal, cheap life, Krug believes “....he could not hope to enjoy (our emphasis) any kind of afterlife simply because he was denied the elementary comfort (our emphasis) of a death chamber" (Nabokov 71). This is the best manifestation of the protagonist's desire for experiencing hereafter, against all his skepticism.

Noticeable is the aesthetic utilization of metaliterary techniques to construct a metaphysical idea. Alexandrov posits that bearing in mind Nabokov's belief that the source of art lies in the otherworld, the metafictional characteristic of this narrative alludes to the metaphysical relation of the human being to hereafter (365). Interestingly, Nabokov referred to the intruding narrator who intervened at the end of the text, and whose voice is heard from time to time, as "an anthropomorphic deity impersonated by me" in the introduction to the novel. Other references to the otherworld are abundant in the text. Some scholars like Rutledge regard water as the emblem of the possibility of communication with the other world for Nabokov (90), and in the curious introduction to the novel the author associated the puddle with Olga's soul and with his own presence above the text (Nabokov 7). Thus, the puddle that first appears in the first chapter, and continues to appear in different formats (ink blot, spilled milk, or footprint of a phosphorescent islander) throughout the text is a sign of the interaction between this world and the realm beyond. Nabokov also introduces the moth that at the end of the novel he can hear its twang at his bright windows as the representative of "Olga's rosy soul" (11). Similar to many critics, Foster considers Olga's soul being present all throughout the text precious, arguing that to Nabokov people's souls continue to live in a hereafter (27).

It is precisely the metafictional rescue of Krug, or from another angle, ending the narrative before Krug finds the chance to be delivered to the otherworld, that we find the most emblematic of totalitarianism's wish to obstruct people's comprehension of a world beyond the materialistic world of the philistines. It has already been noticed by Nabokovian scholars that for this author death is unreal in comparison to the world beyond (Rutledge 80). This is 
something that a number of his characters like Cincinnatus in Invitation to a Beheading and Krug realize in the course of what happens to them in the narratives. As described by Alexandrov, an epiphany occurs to Krug through which he gains the intuition of immortality and timelessness (569), something that can be fully reached after death. Thus, Krug who is mad at the end of the novel cannot even reach eternity through death, something that Cincinnatus, another protagonist of Nabokov, successfully experienced after being decapitated (of course the ending of that novel can be interpreted in a way that he escaped execution). Symbolically, Krug's being forcefully saved by the author-narrator, failing to take his last action against the dictator, and prevented from entering the realm of immortality that he had faith all imply how the materialistic life created by the system prevents people from perceiving the sham of the regimes' standard picture of reality, and keeps them away from the truth of immortality.

\section{FREE INDIVIDUALITY REPRESSED UNDER TOTALITARIANISM}

To perceive the sham of totalitarianism's constructed reality one should be endowed with independent thinking power which is the outcome of being an individualist. In his seminal Nabokov's Permanent Mystery, David Rutledge deems Nabokov's constant subversion of the conventions of Realism as his peculiar way of picturing the inner world more real that the world outside (184). This is due to his firm belief in Individualism, and his attempt to give credit to the personal perceptions of each individual as opposed to the norms they are supposed to take as real and standard. For such an author of prime vitality are his protagonists' thoughts, feelings and reactions in a specific situation. One of the most striking features of Padukgard, according to the author's introduction is paronomasia that the dictator enjoys practicing, by playing with people's names. Although this is an explanation of the word play in this work, "everybody is merely an anagram of everybody else" (Nabokov, 8), the implicit message is the nightmarish fact that the idea of people as different and unique does not make any sense in this dictatorial regime. For instance, the anagram of Adam Krug was Gumakrad or Dramaguk that Paduk, the dictator, had created not out of humor which he did not have any sense of, rather because "one should constantly bear in mind that all men consist of the same twenty five letters variously mixed" (Nabokov 62). Ekwilism is founded based on the belief that all are but one, and that there is one ideal form of living simply because there must not exist any variety in the society. That ideal is to follow the model of Etermon and the kind of life he has, depicted in a cartoon series in a newspaper. What is required of citizens is "letting your person dissolve in the virile oneness of the State" (Nabokov 86). That can remind one of the equality in economics and in society as proclaimed in Communism, but it should be noticed that what is written here is mental uniformity above all, and that is why Etermon or everyman is the basis of Ekwilism that attempts, above all, at suppressing differences and generating collective standards.

It is not difficult to trace the importance of individuality in opposing totalitarianism in this narrative. In the society that citizens do obey the rules of conformity and unanimity, freedom loses its meaning, and the minor part of the people who strive for their independence are either imprisoned or murdered. The deep disdain for the followers of such political madness flows through the text and is depicted in the blatant exaggeration of the stupidity and even grotesque quality of the state functionaries. Even if not the formal soldiers of the system, those who simply admit to the doctrines of the party are pictured as the regime's mouthpieces, resembling the prevalent propaganda of famous dictatorships like Nazism. This is especially evident in the second chapter of the novel that Krug is surrounded by two absolutely stupid soldiers, illiterate apparently, who are unable to understand what a philosopher means. Also, the caricaturistic depiction of the system officials conveys the same picture, for instance, Paduk's physician is described as "an enormous baby-faced man in a dusty- looking frock-coat (Nabokov 122). Rutledge argues that this is total suppression of individualism with obvious affinities to the doctrines of Communism (134).

Padograph, an unbelievable invention of Paduk's father that was able to copy everyone's exact handwriting is the symbol of such repression of individuality. This means that a mere machine can generate personality, and as Grabes argues that is why it represents Ekwilist party; a political doctrine based on the annihilation of the individuality (504). What such totalitarianism steals away from people is their freedom in every possible sense; from the freedom to go where they wish (Krug could not go home because he did not carry the proper passport with himself), up to the most vital freedom- that of mind that enables system to force people live in lies through the duplication of the real, similar yet completely fake. Newspapers in such a system are "published by governmental and public organizations and are absolutely independent of individual, private and commercial interests" (Nabokov 141).This is a lucid example of anagram, not with words but with facts. Such political dictatorship becomes people who are deemed as philistines or masses; incapable of comprehending the truth; "all those who are because they do not think" (Nabokov 19).

The prerequisite of discussing Adam Krug's question of individuality is the thorough comprehension of his role in the text. No doubt, Adam is a mere character in a novel by Vladimir Nabokov, who recognizes his imaginary existence toward the end of the narrative, and yet this very same narrative presents his ideas, dreams, and pains in the most vivid way possible, as if there is a tinge of verisimilitude in this work of metafiction. This issue has already been addressed by scholars such as Foster who states that the particular arrangements of this narrative does not satisfy the common inclination of readers toward granting characters independent existence and individuality, specifically upon the antagonists in Bend Sinister, Paduk and his associates, and instead reduces them to mere puppets at the hand of the author. However, this very same author, who created this puppet show associates the moth with the "rosy soul of Olga" in his introduction, and at the end of the novel writes of a moth that attracts his attention and encourages him to end his work. Granting Olga, a mere character, an ever present soul is the negation of his absolute power over characters as the cre- 
ator of them (27). This metaphysical existence attributed to the wife of the protagonist, the profound thoughts and contemplations of Adam Krug and the authentic, impressive depiction of his pains grant him prepositions above a mere character.

In the country where only the system can approve the existence of people, "From a formal point of view I am not on the bridge at all" (Nabokov 23), Krug strives to maintain his individual opinions and principles to live, as long as possible, according to his individualistic standards. While his colleagues signed the "historic document" (Nabokov 50), everyone looking at others and "seeing that others signed, signed" (Nabokov 52) for the dictator, Adam remained the only one not yielding to what he did not believe in. From the political vantage point, the uniqueness of Krug's ideas, and his being opaque, different from those who simply imitate what others do is what makes him an anti-totalitarian protagonist. As Lee observes, under such heavy spiritual uniformity that the regime is after it is for the sake of protecting his individuality that Krug refuses to endorse the document (194-95).

From a more personal angle, according to the author, Bend Sinister is about love of a father for his son, above all, and it is this love that gives real individuality to Krug. Yet, being an individualist does not suffice for overcoming the ever imposing dominance of the system. Like all real people, Krug has a second self inside who is more coward and less active. This second Krug is the symbol of his endless hesitation and doubts. "...the throbbing man in him was soaked. As usual he discriminated between the throbbing one and the one that looked on... This was the last stronghold of the dualism he abhorred. The square root of I is I" (Nabokov 16). It is this second, poltroon Krug who shows up when the other Krug tries too hard to maintain his control and power as he was looking for his lost son, "I want my little boy, said Krug (another Krug, horribly handicapped by a spasm in the throat and a pounding heart)" (Nabokov 90). One bothering point about Krug is that as a protagonist he does not take any action for changing his and his son's future. The blame is not on his coward self, we believe, rather on his domineering hesitation in taking action, something that links him once more to Hamlet.

What makes the sovereignty of Ekwilist party possible is the triumph of the masses in manipulating the whole society and even forcing intellectuals to obey them. This is what Toker regards as the partial responsibility of an individual trapped in a world gone wrong for this blameworthy path. Thus, the protagonist of Bend Sinister should be considered as part of this "wrong turn" ("Nabokov and Bergson" 371). This responsibility, however, needs to be clarified in the framework of an author who disdained didactic literature. What Krug lacked was not taking part in rebellions or protests, but his ongoing hesitation for what he should do next, or in making a decision for leaving the country, and that is why he resembles a Hamlet figure most (Grabes 503). Krug is torn by his philosophical doubts, about the possibility of life after death, or about the whatness of time, and this philosopher is also doubtful how to treat his little boy after the demise of his wife, how to handle Paduk and his crazy orders, and how to save his and his son's life (finally he decided to escape from the country but it was too late). Of course he did not obey what was dictatorially imposed upon him but as the author-narrator puts it, it is a pity that philosophers and poets are used to esteem words superior to deeds (Nabokov 92); Krug was impotent, like Hamlet. He knew very well that there is something beyond, but for him as a philosopher, feeling absolutely comfortable in writing treatises, it became hard to jot down what his intuition told him, "he was almost incapable of lifting the heavy pencil from the dusty thick carpet" (Nabokov 149), and at the end he started to write what he felt when it was too late. After much conflict with himself, experiencing inability in putting into words what he had the conception of, he suddenly felt ready to express his ideas. As he started writing down his intuition of infinity, he gave in to the temptations of the spy girl, his son's babysitter, and shortly after he was caught by the police. Toker, however, dates Krug's partial responsibility in the rise and dominance of the regime back to his childhood when he was absolutely careless, as a schoolmate of a future dictator, and then due to his absolute absorption in his private occupation and emotion, as a philosopher and a father ("Nabokov's Worldview" 244).

\section{A TOTALITARIAN AUTHOR-NARRATOR}

There is, yet, a more important reason behind Krug's failure against the system that should be sought for, first, in the very introduction of the novel where the initial controlling of reader's interpretation of the narrative begins. The manipulation of readers' expectations and comprehension of the text through forewords and introductions has been the subject of much narratological discussion. No doubt there is a link between the audiences' way of interpreting a work and the provided preamble in the beginning of it. Scholars argue that the voice heard in prefaces stands in between the historical author and its implied version, though Lanser deduces that it is the closest counterpart of the flesh-and-blood author in Booth's terminology (Edelstein 32). Nabokov's works have always been the target of such peritext scrutinies due to a particular Nabokovian voice he maintains in almost all of his prefaces, and because of his usual assertion of disbelief in moral messages or political and social inclinations which has been proved ironic and quite vice versa by recent critics. Added nearly two decades after its first publication, the introduction to Bend Sinister provides its audience with the utter interpretation of the work! the author starts by explaining the main theme of the novel- "the beating of Krug's loving heart, the torture an intense tenderness he is subjected to" (Nabokov 6) -, goes on with dictating the proper understanding of the image of the puddle-“...the puddle vaguely evokes in him my link with him: a rent in his world leading to another world of tenderness, brightness and beauty" (Nabokov 7-8) -, continues with illustrating the symbolic role of the nymph, associated with one of Mallarme's poems that signals destruction- "the widow's heavy sensuality seeks a pathetic outlet in Mariette, but as he avidly claps the haunches of the chance 
nymph he is about to enjoy, a deafening din at the door breaks the throbbing rhythm forever" (Nabokov 10)- and then ends his guide with acknowledging his ever presence throughout the work, popping up first in the beginning of the fifth chapter- "... a mysterious intruder who takes advantage of Krug's dream to convey his own code message....an anthropomorphic deity impersonated by me" (Nabokov 11). It is striking how every little detail of the narrative, impacting its interpretation is explained through this peritext. What is more striking, however, is the amount of authorial control exposed in this 11-page-introduction. This is what Walter deems as guaranteeing the "proper appreciation" of the work (40). Such a peritext reinforces the sense of control and imposed power in the narrative from the very beginning.

The frequent intrusions of the author- narrator range from the most explicit, Krug "had thick (let me see) clumsy (there) fingers" (Nabokov 15), or "what happened to her [Olga] would perhaps not have happened, had I (our emphasis) been in the habit of stopping this or that bit of our common life..." and then switching to the rest of the story: "Krug- for it was still he-..." (Nabokov 21), to the most implicit. For instance, the sudden shift from past tense in the first chapter to present tense in the second one, the switch in pronouns in chapter seven, or addressing the readers, "note also the legend..." (Nabokov 92). Walter argues that quite contrary to his assertion of abhorring didactic literature, it seems as if Nabokov does not give any room to readers' experiencing different parts of the novel but guides his readers to a predesigned scheme of meaning (29).

Mark Curie, a postclassical narrative theorist considers metafiction as theoretical fiction that has a sense of self-consciousness about the construction of its object, affirming and simultaneously denying its authority of referential mode, hinting to metaphysics of reference (62). Bearing in mind the theoretical-philosophical nature of this work, the reason behind such extreme authority imposed on readers becomes the object of scrutiny. We believe that what the intrusive author- narrator attempts at is demonstrating the intensity of control that totalitarianism imposes on people in modern times. For a liberalist author as Nabokov was, such intrusions and manipulations are definitely unacceptable except for the reason of making the novel itself a scene for demonstrating the naked truth about how each individual is bombard by authoritative construction of fake realities, and manipulation of their assumptions and perceptions. This is what narratologists first found in the realistic fictions doing from outside, and Curie argues that the metafiction, as a genre equivalent to criticism does from within (62).

This argument makes sense, specifically when the final intrusion of the author- narrator is considered; he feels pity for his protagonist, first imposes madness on Krug through which he understands his fictional status, and then this narrator ends the story before the last bullet of Paduk's guards kills his protagonist. We believe, Krug, who is blamed, as already discussed, by many scholars for being impotent like Hamlet is in fact deprived of the chance of taking any action against Paduk at the end by the story being finalized before he reaches the dictator. Moreover, unlike Cincinnatus, the protagonist in a close work, who accepted the sham of his decapitation, watched the destruction of the fake world in front of his eyes, and entered the realm of eternal freedom, Krug simply learns that he is nothing but a mere character and is not even that blissful to enter the hereafter about existence of which he became assured toward the end of the narrative. Scholars argue that taking Cincinnatus as just a character and not a verisimilitudinous hero, he still made it to go beyond his fictional boundary into another existence. This is applicable to Krug as well, who had the perception of another world (Wood 201) yet could not overcome the boundaries imposed on him by the author. Wood addresses the same point about Krug's destiny by referring to the fact that becoming mad, forcefully, cannot be regarded as an attractive solution. He continues that "Death is a question of style as long as the death is a written one, that is, doubly someone else's... and belonging to a character made of words...the supposed solution will not help him in his fictional world any more than it would help Nabokov or any other living writer if a god were to drive him crazy and reveal his puppet status" (202). Such intrusive author-narrator, thus, manifests the intensified power of dictatorships that are not conquerable anymore.

Another feature of the peritext, addressed by Booth in his seminal The Rhetoric of Fiction, is a disguised form of rhetoric that is detectable in less noticed properties of the works like their titles (100-101). For Nabokov who proposed that a literary achievement is the product of language and not ideas (qtd. in Lee 194) every word counts for a hidden meaning. It is in fact the language of his work that constructs meaning and conveys it. Thus, the scrutiny of a curious title like Bend Sinister finds other significance, partly due to its complexity that urges the author to dedicate a paragraph to its explanation in the introduction, and partly because of its creator's habit of hiding ideas behind the words. In the introduction Nabokov provides readers with the dictionary definition of the term, "a heraldic bar or band drawn from the left side (and popularly, but incorrectly, supposed to denote bastardy)", and then illustrates his own point in choosing such title, that the choice was his attempt to demonstrate "a wrong turn taken by life, a sinistral and sinister world" (Nabokov 4). This sinister turn of the world is also manifested throughout the text, not just by the story but also through words; for instance, it is ironically in ministry of justice that David is accidentally killed innocently, with no justice done to him. Sinister is, furthermore, the press in Padukgard that is published exclusively by the government, supposedly to immune it from yielding to personal interests of capitalists, while in fact it totally guarantees the interests of the dictatorship. Thus, sinister is a totalitarian system creating a sinister world that blocks individuals' minds in order not to let them go beyond the materialistic framework.

Grishakova asserts that in Nabokov works the hierarchy between the author, narrator, character and the reader (the observer or metaobserver and the observed) is blurred. Hence, she prefers to classify Nabokov's novels as models of involution rather than metafictional or self-conscious novels in order to put the stress on the interaction between the pro- 
tagonist and the author-narrator. Narratologically speaking, this means the dissolution of the border between the diegetic fictional plan and the extradiegetic implied author (96-97). Patricia Waugh whose great contribution to the study of metafiction is much appreciated by narrative theorists borrows from Barthes's death of the author and proposes that by eroding the protocol of distinguishing author from implied author from narrator, it becomes easier to focus on the fact that it is the reader that being influenced by linguistic, cultural and artistic conventions invents the author (134). Bend Sinister, therefore, should be understood as what contemporary readers, who have undergone the aftermath of the two World Wars and have suffered from the modern world when as Marx said "everything that is solid melts into the air", comprehend and feel.

We believe that above all, this novel is about individuals' minds, enslaved and confined in the constructed lies of all totalitarian systems, apparently unable, at least for as long as this is the way of the world, to reach freedom. For Krug, the philosopher-protagonist who strived for infinite freedom (Grishakova 260) there could not be a worse obstacle than a dictatorial narrator. Its sinister presence is felt by Krug when the narrator describes the philosopher's discussion about Hamlet with Ember by using present tense as if he is giving a report of his spying on the philosopher and his friend. Before the arrest of Ember, Krug feels that they are spied on, probably by Ekwilist soldiers. It is the final intrusion of this author-narrator, blessing the protagonist by madness and then ending the narrative before Krug's death that Wood considers as much disputable, not denoting any favorable ending, signaling, instead, the fact that our modern time witnesses the realization of the nightmarish rise of the once imaginary totalitarian systems (202).

\section{CONCLUSION}

In this article, the researchers have discussed the narrative structures and the rhetorical design of Bend Sinister in search of its definition of genuine freedom. Invitation to a Beheading, as discussed above, is another attempt of Nabokov's to narrate his peculiar understanding of totalitarianism and freedom. Focusing initially on the presented reality in the novel, we have discussed the sense of confinement that time and space imposed on Krug and his struggle, in the process of gaining knowledge of his state as a mere character, with his intermediary state between dream and reality. The relentless propaganda of the system presented the materialistic world as the ultimate truth, confining citizens in the prison of a fake world and not allowing them to have the scantest awareness of the infinite freedom possible in eternity. Addressing the question of individuality, further, we have indicated that the metaphysical notions of the work bestow Krug properties above a mere character. His attempts not to yield to the desired system of padograph help him to maintain his individuality and reach the truth about the real life and also real freedom-here, freedom of mind. Nonetheless, he is deprived of a real death that could transfer him to the transcendental realm of eternity. The omnipotent author-narrator of the novel takes advantage of the peritext and the final scene of the novel to demonstrate that totalitarianism in modern times has gained such absolute power that no thorough freedom of mind is now imaginable for humanity.

\section{REFERENCES}

Alexandrov, Vladimir E. "The Otherworld." The Garland Companion to Vladimir Nabokov. Ed. Vladimir E. Alexandrov. New York: Rutledge, 1995. 566-70. Web.

Begnal, Michael H. "'Bend Sinister": Joyce, Shakespeare, Nabokov." Modern Language Studies 15.4 (1985): 2227. Web. 12 Sep. 2015.

Booth, Wayne C. The Rhetoric of Fiction. $2^{\text {nd }}$ ed. Chicago: U of Chicago, 1963. Web.

Boyd, Brian. "Nabokov as Storyteller." The Cambridge Companion to Nabokov. Ed. Julian W. Connolly, New York: Cambridge UP, 2005. 31-48. Web.

Ciancio, Ralph A. "Nabokov and the Verbal Mode of the Grotesque.” Contemporary Literature 18.4 (1977): 50933. Web. 19 Sept. 2015.

Currie, Mark. Postmodern Narrative Theory. London: Macmillan, 1998. Web.

Edelstein, Marilyn. "Before the Beginning." Narrative Beginnings: Theories and Practices. Ed. Brian Richardson. Lincoln: U of Nebraska, 2008. 29-43. Web.

Foster, John Burt, Jr. “Bend Sinister." The Garland Companion to Vladimir Nabokov. Ed. Vladimir E. Alexandrov. New York: Rutledge, 1995. 25-36. Web.

Grishakova, Marina. The Models of Space, Time and Vision in V. Nabokov's Fiction: Narrative Strategies and Cultural Frames. Tartu: Tartu UP, 2006. Web.

Grabes, Herbert. "Nabokov and Shakespeare: The English Works." The Garland Companion to Vladimir Nabokov. Ed. Vladimir E. Alexandrov. New York: Rutledge, 1995. 482-511. Web.

Kuzmanovich, Zoran. "Strong Opinions and Nerve Points: Nabokov's Art and Life." The Cambridge Companion to Nabokov. Ed. Julian W. Connolly. New York: Cambridge UP, 2005. 11-30. Web.

Lee, L. L. "'Bend Sinister": Nabokov's Political Dream." Wisconsin Studies in Contemporary Literature 8.2 (1967): 193-203. Web. 19 Sept. 2015.

Momeni, Javad, and Bahare Jalali Farahani. "Narrative Theory: A Shift towards Reader's Response." International Journal of Current Advanced Research 5.8 (2016): 1146-1153. Web.

Nabokov, Dmitri, and Mathew J. Bruccoli, eds. Vladimir Nabokov Selected Letters 1940-1977. New York: n.p., 1989. Web.

Nabokov, Vladimir Vladimirovich. Bend Sinister. New York: Time, 1964. Ebook.

Rimmon-Kenan, Shlomith. Narrative Fiction: Contemporary Poetics. London: Methuen, 1983. Web.

Rutledge, David S. Nabokov's Permanent Mystery: The Expression of Metaphysics in His Work. Jefferson, NC: McFarland, 2011. Web.

Schuman, Samuel. "Beautiful Gate: Vladimir Nabokov and Orthodox Iconography." University of Notre Dame 
32.1 (2000): 47-66. Web. 19 Sep. 2015.

Toker, Leona. "Nabokov and Bergson." The Garland Companion to Vladimir Nabokov. Ed. Vladimir E. Alexandrov. New York: Rutledge, 1995. 367-73. Web.

---. "Nabokov's Worldview." The Cambridge Companion to Nabokov. Ed. Julian W. Connolly. New York: Cambridge UP, 2005. 232-47. Web.

Walter, Brian D. "Two Organ-Grinders Duality and Dis- content in Bend Sinister." Discourse and Ideology in Nabokov's Prose. Ed. David H. J. Larmour. New York: Rutledge, 2002. 24-40. Web.

Waugh, Patricia. Metafiction: The Theory and Practice of Self-conscious Fiction. London: Methuen, 1984. Web.

Wood, Michael. "Nabokov's Late Fiction." The Cambridge Companion to Nabokov. New York: Cambridge UP, 2005. 200-13. Web. 